\title{
PEMERIKSAAN PAPSMEAR PADA WANITA USIA SUBUR (WUS) DI KECAMATAN SUSOH KABUPATEN ACEH SELATAN
}

\section{PAPSMEAR EXAMINATION ON WOMEN OF FERTILE AGE (WUS) IN SUSOH DISTRICT, SOUTH ACEH REGENCY}

\author{
Fauziah Andika ${ }^{1}$, Faradilla Safitri ${ }^{2}$, Ayuni Safira ${ }^{3}$ \\ ${ }^{1,2,3}$ Fakultas Ilmu Kesehatan, Universitas Ubudiyah Indonesia \\ Email: fauziah@uui.ac.id
}

\begin{abstract}
ABSTRAK
Peningkatan terhadap kejadian kanker leher Rahim memerlukan adanya tindakan pencegahan, diantaranya vaksinasi (pencegahan primer) dan skrining atau deteksi dini dengan pap smear (pencegahan sekunder). Puskesmas di kecamatan Susoh menjadi kecamatan terendah ke 5 dari 13 Puskesmas di kecamatan lain yang ada di Aceh barat Daya untuk tingkat cakupan pemeriksaan Pap Smear/IVA Test terhadap Wanita Usia Subur. Hal ini menunjukkan masih sangat rendah tingkat kesadaran Wanita Usia Subur untuk melakukan pemeriksaan Pap Smear. Rendahnya tingkat kesadaran wanita terhadap Pap Smear bisa ddipengaruhi karena rendahnya tingkat pengetahuan terhadap Pap Smear. Tujuan penelitian ini adalah untuk mengetahui factor yang berhubungan dengan pengetahuan WUS tentang pemeriksaan Pap smear. Metode penelitian ini adalah deskriptif analitik dengan pendekatan crossectional. Populasi pada penelitian ini berjumlah 72 orang dengan jumlah sampel 31 orang. Pengumpulan data diambil pada tanggal 12 Juni dan 13 Juni 2020. Analisa data yang digunakan analisa univariat dan bivariate dengan uji staistik ChiSquare dengan CI 95\%. Hasil penelitian didapatkan hasil hubungan pengetahuan WUS tentang pemeriksaan Pap smear dengan umur $(\mathrm{p}=1.000)$ pendidikan $\mathrm{p}(=0.042)$ dan sikap $(\mathrm{p}=0.002)$. Kesimpulan dari penelitian ini adalah ada hubungan antara pendidikan dan sikap dengan pengetahuan WUS tentang pemeriksaan Papsmear dan tidak ada hubungan antara umur dengan pengetahuan WUS tentang pemeriksaan Papsmear.
\end{abstract}

Kata Kunci: Umur, Pendidikan, sikap, pengetahuan WUS tentang pemeriksaan Pap smear

\begin{abstract}
The increase in the incidence of cervical cancer requires prevention measures, including vaccination (primary prevention) and screening or early detection with pap smears (secondary prevention). The Puskesmas in Susoh sub-district is the fifth lowest sub-district out of 13 Puskesmas in other sub-districts in Southwest Aceh for the level of coverage of Pap Smear / IVA tests for women of fertile age. This shows that the level of awareness of fertile age women is still very low to do a Pap smear. The low level of women's awareness of the Pap Smear can be affected because of the low level of knowledge about Pap Smears. The purpose of this study was to determine the factors associated with WUS knowledge about Pap smear examination. This research method is descriptive analytic with cross sectional approach. The population in this study amounted to 72 people with a sample size of 31 people. Data collection was taken on 12 June and 13 June 2020. Data analysis used univariate and bivariate analysis with Chi-Square statistical test with $95 \%$ CI. The results showed the relationship between WUS knowledge about Pap smear examination with
\end{abstract}


Journal of Healthcare Technology and Medicine Vol. 6 No. 2 Oktober 2020

Universitas Ubudiyah Indonesia

e-ISSN : 2615-109X

age ( $p=1,000)$, education, $p(=0.042)$ and attitude $(p=0.002)$. The conclusion of this study is that there is a relationship between education and attitudes with knowledge of WUS about Pap smear examination and there is no relationship between age and knowledge of WUS about Pap smear examination.

Keywords: Age, education, attitudes, knowledge of WUS about Pap smear examination

\section{PENDAhuluan}

Kanker merupakan suatu masalah kesehatan di berbagai negara termasuk Indonesia. Hasil pemeriksaan patologi menyatakan kanker leher rahim, payudara, kelenjar getah bening, kulit dan nasofaring merupakan lima kelompk kanker terbanyak di Indonesia (Abdullah et al., 2013). Adanya bahaya kanker leher rahim karena kurangnya kesadaran khususnya wanita di Indonesia tentang perlunya dilakukan tindakan promotif-preventif, diantaranya dengan sosialisasi, advokasi, dan edukasi di masyarakat. minimal $80 \%$ pemerintah menargetkan perempuan usia 30-55 tahun melakukan deteksi dini setiap 5 tahun dalam pencegahan kanker leher rahim,salah satunya pemeriksaan pap smear (Junita, 2013).

Penyakit kanker merupakan salah satu penyakit yang tidak menular. Pada tahun 2012, kanker menjadi penyebab kematian utama di seluruh dunia sekitar 8,2 juta orang. Penyakit kanker juga merupakan salah satu fokus utama Sustainable Development Goals (SDGs) yaitu pembangunan berkelanjutan sebagai agenda pembangunan global baru untuk 2016 hingga 2030 meneruskan pencapaian Millenium Development Goals (MDGs) yang telah berakhir pada tahun 2015. SDGs berisi tujuh belas tujuan salah satunya tujuan ketiga adalah kesehatan dan kesejahteraan (Pusat data dan informasi kementerian RI, 2015). Maksud tujuan yang ketiga SDGs untuk meningkatkan kesehatan yang baik dengan target yang akan dicapai yaitu mengurangi sepertiga kematian akibat penyakit tidak menular. (Kemenkes, 2015)

Kanker leher rahim di negara berkembang termasuk indonesia menduduki urutan kedua setelah kanker payudara sebagai penyebab kematian sebesar 260.000 kasus dan apabila tidak ditindaklanjuti dengan segera, diperkirakan akan meningkat $25 \%$ pada sepuluh tahun mendatang (Dewi et al.,2013).

Berdasarkan data dari Global Cancer Observatory tahun 2018 Indonesia merupakan negara berkembang yang angka penderita kanker serviks sangat tinggi dan merupakan salah 
satu penyebab kematian wanita setiap tahunnya. Dimana angka mortaliti akibat kanker serviks sebanyak 18.279 (8,8\%), sedangkan angka morbiditi akibat kanker serviks juga tinggi yaitu sebesar 32.468 (9,3\%). (WHO, 2018).

Peningkatan terhadap kejadian kanker leher Rahim memerlukan adanya tindakan pencegahan, diantaranyan vaksinasi (pencegahan primer) dan skrining atau deteksi dini dengan pap smear (pencegahan sekunder). Tindakan pencegahan dengan pap smear dilakukan untuk mendeteksi adanya sel-sel abnormal yang lebih akurat dan praktis sedangkan vaksinasi bekerja dengan meningkatkan antibody tubuh, dimana keefektifan vaksinasi dapat optimal setelah pemberian pemberian berulang sebnayak 3 kali sehingga hal tersebut membuat individu tidak melakukan vaksinasi kembali setelah pemberian pertama. Adapun kelemahan lain dari yaitu risiko mendapat infeksi baru sangat bergantung pada perilaku seksual dari individu, dimana perilaku seksual yang sering berganti-ganti pasangan seksual menyebabkan kefektifan vaksinasi menurun (Komalasari, 2012).

Kelebihan pap smear sendiri yaitu pap smear mudah dilakukan dan tidak menimbulkan rasa sakit (Harahap, 2013). Kelebihan lain dari pap smear yaitu aman dan murah untuk mendeteksi kelainan atau lesi prakanker pada epitel leher Rahim (Sirait, 2013). Pap Smear merupakan salah satu metode deteksi dini dnegan pemeriksaan sel dengan diambil dari leher Rahim untuk di deteksi lebih dini yang memungkinkan pengobatan sebelum sel abnormal dapat berkembang menjadi lesi prakanker atau kanker serviks sedini mungkin, terutama pada wanita yang melakukan seksual aktif, walaupun yang sudah divaksinasai (Yanti, 2013).

Keberhasilan pap smear di negara berkembang dapat menurunkan angka kejadian kanker leher Rahim hingga 50\% dan dapat menurunkan angka kematian hingga 3-55\% (Martini, 2013). Beberapa factor yang mempengaruhi seseorang dalam tindakan pap smear diantaranya: Faktor predisposisi (predisposing factor) seperti pengetahuan, sikap, tingkatan social ekonomi dan pengalaman ; factor pemungkin (enabling factors), seperti lingkungan fisik dengan tersedianya tempat pelayanan kesehatan yang terjangkau masyarakat dan factor penguat (reinforcing factors), seperti keluarga, kelompok, guru, petugas kesehatan dan pengambil keputusan yang mendukung untuk melakukan tindakan papsmear (Martini, 2013). 
Journal of Healthcare Technology and Medicine Vol. 6 No. 2 Oktober 2020

Universitas Ubudiyah Indonesia

e-ISSN : 2615-109X

Berdasarkan Riset Kesehatan Dasar (Riskesdas) 2013 Kementrian Kesehatan Republik Indonesia dan Pusat Data dan Informasi (Pusdatin) Kementrian Kesehatan Republik Indonesia prevalensi kanker serviks di Aceh sebesar 1.401 atau sebesar 0,6\% . Menurut Kepala Badan Penyelenggara Jaminan Sosial (BPJS) Kesehatan kota Banda Aceh thaun 2017, kasus kanker serviks di Aceh meningkat setiap tahunnya yaitu naik sebesar 15 persen sampai tahun 2017.

Berdasarkan Profil Kesehatan tahun 2018, Presentase cakupan pemeriksaan deteksi dini kanker serviks dan payudara pada perempuan usia 30-50 tahun menurut provinsi sampai dengan tahun 2018, Aceh berada pada posisi lima terbawah dengan hanya 2,64\% wanita usia subur di Aceh yang telah melakukan pemeriksaan deteksi dini kanker serviks (Pap Smear), sedangkan Bangka Belitung pada posisi pertama dengan presentase 25,42\%. Hal ini menunjukkan bahwa WUS di Aceh masih sangat kurang minat terhadap pemeriksaan deteksi dini kanker serviks Pap Smear.

Berdasarkan data rekapitulasi Dinas Kesehatan kabupaten Aceh Barat Daya tahun 2015 s/d 2019 mengenai cakupan pelaksanaan pemeriksaan Pap Smear/IVA Test di seluruh Puskesmas yang ada di kecamatan di Aceh Barat Daya menunjukkan hanya 346 orang dari 32.056 Wantia Usia Subur yang pernah melakukan pemeriksaan Pap Smear/IVA Test. Sedangkan di Puskesmas kecamatan Susoh, hanya 15 orang dari 2.879 Wanita Usia Subur yang pernah melakukan pemeriksaan Pap Smear/IVA Test. Hal ini menempatkan Puskesmas di kecamatan Susoh menjadi kecamatan terendah ke 5 dari 13 Puskesmas di kecamatan lain yang ada di Aceh barat Daya untuk tingkat cakupan pemeriksaan Pap Smear/IVA Test terhadap Wanita Usia Subur. Hal ini menunjukkan masih sangat rendah tingkat kesadaran Wanita Usia Subur untuk melakukan pemeriksaan Pap Smear. Rendahnya tingkat kesadaran wanita terhadap Pap Smear bisa ddipengaruhi karena rendahnya tingkat pengetahuan terhadap Pap Smear. (Dinas Kesehatan Aceh Barat Daya, 2020).

\section{METODE PENELITIAN}

Metode penelitian ini adalah deskriptif analitik dengan pendekatan crossectional. Populasi pada penelitian ini berjumlah 72 orang dengan jumlah sampel 31 orang. Pengumpulan data diambil pada tanggal 12 Juni dan 13 Juni 2020. Analisa data yang digunakan analisa univariat dan bivariate dengan uji staistik Chi-Square dengan CI 95\%. 


\section{HASIL DAN PEMBAHASAN}

\section{Analisis Univariat}

Tabel 1.1. : Distribusi Frekuensi Pengetahuan, Umur, Pendidikan dan Sikap WUS tentang pemeriksaan papsmear di Desa Baharu Kecamatan Susoh Kabupaten Aceh Selatan

\begin{tabular}{c|lcc}
\hline NO & \multicolumn{1}{|c}{ VARIABEL } & FREKUENSI & $\begin{array}{c}\text { PERSENTASE } \\
(\boldsymbol{\%})\end{array}$ \\
\hline $\mathbf{1}$ & Pengetahuan & 13 & 41.9 \\
& $-\quad$ Rendah & 18 & 58.1 \\
$\mathbf{2}$ & $-\quad$ Tinggi & 17 & 54.8 \\
& Umur & 14 & 45.2 \\
& $-\quad$ Tidak Produktif & & \\
$\mathbf{3}$ & $-\quad$ Produktif & 16 & 51.6 \\
& Pendidikan & 15 & 48.4 \\
& $-\quad$ Menengah & & \\
$\mathbf{4}$ & - Tinggi & 15 & 48.4 \\
& Sikap & 16 & 51.6 \\
& $-\quad$ Negatif & & \\
& $-\quad$ Positif & & \\
\hline
\end{tabular}

Berdasarkan distribusi frekuensi pengetahuan, umur, pendidikan dan Sikap WUS tentang pemeriksaan papsmear dapat dilihat bahwa $58.1 \%$ responden memiliki pengetahuan tinggi lebih banyak dibandingkan dengan responden berpengetahuan rendah yaitu sebesar 41.9\%. pada umur responden sebesar 54.8\% responden memiliki umur tidak produktif yaitu usia $>35$ tahun dan $45.2 \%$ responden memiliki umur produktif. Dilihat dari tingkat pendidikan, responden dengan pendidikan menengah lebih banyak yaitu 51.6\% dibandingkan dengan responden dengan pendidikan tinggi yaitu sebesar $48.4 \%$. Sedangkan untuk variabel sikap, responden yang memiliki sikap positif lebih banyak dibandingkan dengan responden yang memiliki sikap negatif yaitu sebesar 51.6\%.

Tabel 2. : Hubungan Antara Umur, Pendidikan dan sikap dengan Pengetahuan WUS tentang pemeriksaan papsmear di Desa Baharu Kecamatan Susoh Kabupaten Aceh Selatan

\begin{tabular}{llllll}
\hline No & Variabel & \multicolumn{3}{c}{ Pengetahuan } & $p$ value \\
& Rendah & Tinggi & \\
& n & $\%$ & n & $\%$ & \\
\hline
\end{tabular}




\begin{tabular}{llccccc}
\hline 1 & Umur & 7 & 41.2 & 10 & 58.8 & 1.000 \\
a. Tidak Produktif & 6 & 42.9 & 8 & 57.1 & \\
b. Produktif & & & & & \\
2 & Pendidikan & 10 & 62.5 & 6 & 37.5 & 0.042 \\
& $\begin{array}{l}\text { a. Menengah } \\
\text { b. Tinggi }\end{array}$ & 3 & 20.0 & 12 & 80.0 & \\
3 & Sikap & & & & & \\
a. Negatif & 11 & 73.3 & 4 & 26.8 & 0.002 \\
b. Positif & 2 & 12.5 & 14 & 87.5 & \\
\hline
\end{tabular}

Berdasarkan tabel 2. Menunjukkan bahwa dari 17 responden dengan umur tidak produktif dan berpengetahuan tinggi yaitu sebesar 58.8\% lebih besar dibandingkan dengan dari 14 responden dengan umur produktif dan berpengatahuan tinggi yaitu sebesar 57.1\%. Berdasarkan hasil uji statistic didapatkan nilai $\mathrm{P}=1.000$, artinya tidak ada hubungan antara umur dengan pengetahuan WUS tentang pemeriksaan papsmear di Desa Baharu Kecamatan Susoh Kabupaten Aceh Selatan.

Sedangkan pada hubungan pendidikan dengan pengetahuan dapat dilihat bahwa dari 16 responden dengan pendidikan menengah dan berpengetahuan tinggi memiliki presentase sebesar 62.5\% lebih besar dibandingkan dengan dari 15 responden berpendidikn tinggi yaitu sebesar $20 \%$. Hasil uji statistic didapatkan bahwa $\mathrm{P}$ Value $=0.042$ artinya ada hubungan antara pendidikan dengan pengetahuan WUS tentang pemeriksaan papsmear di Desa Baharu Kecamatan Susoh Kabupaten Aceh Selatan.

Hubungan sikap dengan pengetahuan WUS tentang pemeriksaan papsmear dapat dilihat dari 15 responden bersikap negative dan berpengetahuan rendah yaitu sebanyak 73.3\% lebih besar dibandingkan dengan responden dengan sikap positif yaitu sebesar $12.5 \%$. berdasarkan hasil uji statistic didapatkan nilai $\mathrm{P}=0.002$ artinya ada hubungan yang signifikan antara sikap dengan pengetahuan WUS tentang pemeriksaan papsmear di Desa Baharu Kecamatan Susoh Kabupaten Aceh Selatan.

\section{Pembahasan}

\section{Hubungan Umur dengan Pengetahuan WUS tentang Pemeriksaan Papsmear}


Berdasarkan tabel 2. Menunjukkan bahwa dari 17 responden dengan umur tidak produktif dan berpengetahuan tinggi yaitu sebesar $58.8 \%$ lebih besar dibandingkan dengan dari 14 responden dengan umur produktif dan berpengatahuan tinggi yaitu sebesar $57.1 \%$. Berdasarkan hasil uji statistic didapatkan nilai $\mathrm{P}=1.000$, artinya tidak ada hubungan antara umur dengan pengetahuan WUS tentang pemeriksaan papsmear di Desa Baharu Kecamatan Susoh Kabupaten Aceh Selatan.

Penelitian ini tidak sejalan dengan penelitian wawan yaitu ada hubungan yang signifikan antara umur dengan Pengetahuan wanita Usia Subur tentang Pap Smear. Pengetahuan atau kognitif merupakan domain yang sangat penting untuk terbentuknya tindakan seseorang (over behavior). Berdasarkan pengalaman dan penelitian perilaku yang didasari oleh pengetahuan akan langgeng dibandingkan perilaku yang tidak didasari oleh pengetahuan. Pengetahuan dipengaruhui beberapa faktor diantaranya adalah umur, dimana umur menggambarkan kematangan fisik, psikis dan sosial yang mempengaruhi proses belajar mengajar. Ini berarti bahwa umur merupakan salah satu faktor yang mempengaruhi penangkapan informasi yang pada akhirnya berpengaruh pada peningkatan pengetahuan seseorang, termasuk pengetahuan tentang pap smear (Wawan, 2010).

Usia seseorang juga mempengaruhi terhadap daya tangkap dan pola pikir seseorang. Semakin bertambah usia akan semakin berkembang pula daya tangkap dan pola pikirnya, sehingga pengetahuan yang diperolehnya semakin baik. Pada usia 20-35 tahun, individu akan lebih berperan aktif dalam masyarakat dan kehidupan sosial serta lebih banyak melakukan persiapan demi suksesnya upaya menyesuaikan diri menuju usia tua. Selain itu, mereka akan lebih banyak menggunakan banyak waktu untuk membaca. Kemampuan intelektual, pemecahan masalah dan kemampuan verbal dilaporkan hampir tidak ada penurunan pada usia ini (Erdian, 2009).

Berdasarkan hasil dilapangan dapat diketahui bahwa umur tidak berpengaruh atau berhubungan dengan pengetahuan seseorang. Karena ada variabel lain yang berhubungan dengan pengetahuan WUS tentang Pap smear, yaitu variabel pendidikan dan sikap.

\section{Hubungan Pendidikan dengan Pengetahuan WUS tentang Pemeriksaan Pap Smear}


Journal of Healthcare Technology and Medicine Vol. 6 No. 2 Oktober 2020

Universitas Ubudiyah Indonesia

e-ISSN : 2615-109X

Hubungan pendidikan dengan pengetahuan dapat dilihat bahwa dari 16 responden dengan pendidikan menengah dan berpengetahuan tinggi memiliki presentase sebesar $62.5 \%$ lebih besar dibandingkan dengan dari 15 responden berpendidikn tinggi yaitu sebesar 20\%. Hasil uji statistic didapatkan bahwa $\mathrm{P}$ Value $=0.042$ artinya ada hubungan antara pendidikan dengan pengetahuan WUS tentang pemeriksaan papsmear di Desa Baharu Kecamatan Susoh Kabupaten Aceh Selatan.

Tingkat pendidikan seseorang akan mempengaruhi penerimaan dan pemahaman terhadap suatu objek atau materi yang dimanifestasikan dalam bentuk pengetahuan. Semakin tinggi tingkat pendidikan seseorang, akan mempengaruhi tingkat penguasaan terhadap materi yang harus dikuasai sesuai dengan tujuan dan sasaran. Pengetahuan yang adekuat, akan membuat seseorang mampu mengambil keputusan dalam tindakan yang akan dilakukan.

Pendidikan yang dimiliki seseorang dapat mengembangkan kepribadian agar lebih bernilai (Hasbullah, 2011), sehingga wanita usia subur akan mengembangkan dirinya dengan membaca dan mendapat informasi dari luar yang dapat memperbanyak pengetahuan. Dalam hal ini pengetahuan wanita usia subur baik karena wanita usia subur mengembangkan dirinya dengan mendapatkan informasi dari luar misalnya melalui interaksi sosial seperti arisan, pengajian dan pertemuan- pertemuan antar warga misalnya dengan cara wanita usia subur yang telah melakukan pap smear berbagi pengalaman dengan mereka yang belum pernah melakukan pap smear.

Hasil penelitian ini sejalan dengan penelitian wardani (2018), dari hasil penelitian menunjukkan bahwa semakin tinggi tingkat pendidikan wanita usia subur maka semakin tinggi pula pengetahuan wanita usia subur. Hasil tersebut berdasarkan uji Rank Spearman dengan nilai kemaknaan $\alpha=0,05$ didapatkan nilai $\rho=0,000$ yang berarti $\rho<\alpha$ maka $\mathrm{H}_{0}$ ditolak artinya ada hubungan antara tingkat pendidikan wanita usia subur dengan pengetahuan wanita usia subur tentang pap smear. Dari hasil penelitian menunjukkan bahwa semakin tinggi tingkat pendidikan wanita usia subur maka semakin tinggi pula pengetahuan wanita usia subur tersebut.

\section{Hubungan Sikap dengan Pengetahuan WUS tentang Pemeriksaan Pap Smear}

Hubungan sikap dengan pengetahuan WUS tentang pemeriksaan papsmear dapat dilihat dari 15 responden bersikap negative dan berpengetahuan rendah yaitu sebanyak $73.3 \%$ 
lebih besar dibandingkan dengan responden dengan sikap positif yaitu sebesar $12.5 \%$. berdasarkan hasil uji statistic didapatkan nilai $\mathrm{P}=0.002$ artinya ada hubungan yang signifikan antara sikap dengan pengetahuan WUS tentang pemeriksaan papsmear di Desa Baharu Kecamatan Susoh Kabupaten Aceh Selatan.

Penelitian ini sejalan dengan Djoar (2018), Hasil identifikasi antara tingkat pengetahuan dengan sikap ibu dilakukan uji statistik Rank Spearman dengan $\mathrm{p}=0,000$ sehingga $\mathrm{H} 1$ di terima berarti ada hubungan antara tingkat pengetahuan dengan sikap ibu tentang pap smear sebagai deteksi dini kanker serviks di RW V Kelurahan Darmo, Kecamatan Wonokromo Surabaya. Semakin positif sikap ibu maka semakin baik pengetahuan WUS tentang pemeriksaan Pap smear.

Menurut Azwar, (2005) salah satu faktor pembentuk sikap manusia adalah media massa, dimana media massa membawa pesan-pesan yang berisi sugestif yang dapat mengarahkan opini seseorang. Pesan- pesan sugestif yang dibawa oleh informasi tersebut, apabila cukup kuat, akan memberi dasar afektif dalam menilai sesuatu hal sehingga terbentuk arah sikap tertentu. Responden yang telah mendapat informasi melalui media cetak tetapi memiliki sikap negatif disebabkan oleh sulitnya memahami informasi yang disampaikan sehingga responden kurang memahami pesan-pesan yang disampaikan.

Berdasarkan asumsi peneliti semakin baik atau semakin positif sikap WUS maka semakin tinggi pula pengetahuan WUS tentang pemeriksaan Pap smear. Positifnya sikap WUS dapat mempengaruhi perilaku WUS untuk melakukan pemeriksaan pap smear. Pada WUS yang memiliki pengetahuan tinggi sudah banyak yang memiliki kesadaran dalam pemeriksaan pap smear secara rutin. WUS

\section{KESIMPULAN}

Berdasarkan penelitian yang sudah dilakukan dapat disimpulkan bahwa ada hubungan antara pendidikan dan sikap dengan pengetahuan WUS tentang pemeriksaan papsmear dengan nilai $\mathrm{P}<0.05$. Sedangkan umur dengan pengetahuan WUS tentang pemeriksaan papsmear tidak memiliki hubungan dengan nilai $\mathrm{P}<0.05$

\section{DAFTAR PUSTAKA}


Journal of Healthcare Technology and Medicine Vol. 6 No. 2 Oktober 2020

Universitas Ubudiyah Indonesia

e-ISSN : 2615-109X

[1] Abdullah S., Jaevery B., Rivelino H., 2013. Hubungan Pemakaian Kontrasepsi Hormonal dan Non Hormonal dengan Kejadian Kanker Serviks di Ruang D Atas Blu, Prof, DR, R. D. Kandou Manado. E-Jurnal Keperawatan (EKp). 1:1-7

[2] Dewi, M.R; Purnami, S.W. 2015. Klasifikasi Hasil Pap Smear Test sebagai Upaya Pencegahan Sekunder Penyakit Kanker Serviks di Rumah Sakit " $X$ " Surabaya Menggunakan Piecewise Polynomial Smooth Support Vector Machine (PPSSVM). Jurnal Sains dan seni ITS; 4;(1) p2337-3520.

[3] Erdian. 2009. Ilmi Perilaku, cetakan pertama. Jakarta: CV Sagung Seto

[4] Erika Martining Wardani, Eppy Setiyowati. 2018. Hubungan Pendidikan Dengan Pengetahuan Wanita Usia Subur Tentang Pap Smear Di Pondok Pesantren Al Hidayah Kendal Ngawi. Jurnal Ilmiah Kesehatan, Vol 13. No 1. Februari 2018, hal 92-96

[5] Harahap S., 2013. Analisis Pengetahuan dan Sikap Ibu Rumah Tangga Terhadap Pelaksanaan Pap Smear Untuk Deteksi Dini Kanker Serviks di Puskesmas Petisah Medan Tahun 2013. Thesis. Medan : Fakultas Kedokteran Universitas Sumatera Utara Medan

[6] Hasbullah. (2001). Dasar-Dasar Ilmu Pendidikan. Jakarta: Pustaka Populer Obor

[7] Junita F., 2013. Hubungan Tingkat Pengetahuan Ibu Tentang Kanker Serviks dengan Pemeriksaan Pap Smear di Rumah Sakit Umum Daerah Kota Bekasi. Skripsi. Bekasi : Sekolah Tinggi Ilmu Kesehatan Medistra Indonesia Bekasi

[8] Kumalasari,Intan. (2012). Kesehatan Reproduksi. Jakarta: Salemba Medika.

[9] Martini, Ni Ketut. 2013. TESIS : Hubungan Karakteristik, Pengetahuan dan Sikap Wanita Pasangan Usia Subur dengan Tindakan Pemeriksaan Pap Smear di Puskesmas Sukawati II

[10] Pusat Data dan Informasi. 2015. Situasi Penyakit Kanker. Kementrian Kesehatan RI : Buletin Jendela Data dan Informasi.

[11] Profil Kesehatan Provinsi Aceh. 2016. Profil Kesehatan Provinsi Aceh Tahun 2016. Aceh: Dinas Kesehatan Provinsi Aceh.

[12] Profil Desa Baharu Kecamatan Susoh. 2018. Profil Desa Baharu Tahun 2018. Aceh Barat daya: Pemerintah Kabupaten Aceh Barat daya.

[15] Raditya Kurniawan Djoar, Ni Luh Dian Meiliantariasih. 2014.Hubungan Tingkat Pengetahuan Dengan Sikap Ibu Tentang Pap Smear Sebagai Deteksi Dini Kanker Serviks. Jurnal Penelitian Kesehatan, Jilid 2, nomor 1, November 2014, hlm. 23-28

[16] Riskesdas. 2013.Badan Penelitian Dan Pengembangan Kesehatan Kementerian Kesehatan RI Tahun 2013. 
[17] Sirait, I., 2013. Hubungan Pengetahuan dengan sikap Pasangan Usia Subur tentang Pemeriksaan Pap Smear di Kelurahan Bane, Kecamatan Siantar Utara. http://repository.usu.ac.id/handle/123456789/45251, 4 Agustus 2020

[18] Wawan A dan M.Dewi. 2010. Teori dan Pengukuran Pengetahuan, Sikap, dan Perilaku Manusia. Yogyakarta : Nuha Medika

[19] Yanty N. V., 2013. Hubungan Tingkat Pengetahuan Ibu Tentang Kanker Serviks dengan Perilaku Ibu dalam Melakukan Test Pap Smear di Kelurahan Tugu Utara. Skripsi. Jakarta : Fakultas Kedokteran Universitas Islam Negeri Syarif Hidayatullah Jakarta 